\title{
TRADISI MEUGANG DALAM MASYARAKAT ACEH: Sebuah Tafsir Agama dalam Budaya
}

\author{
Marzuki \\ UIN Ar Raniry Banda Aceh \\ Email: marzukiabubakar84@gmail.com
}

\begin{abstract}
Meugang is a tradition preserved by the people of Aceh to date. It is hold to welcome Ramadan, Idul Fitri and Eid al-Adha. It is a manifestation of a religious interpretation practiced in a form of Acehnese culture. How is mengang tradition in the society? Why this culture is believed to be part of the religion and operates as religious interpretation in people's life? This study answers them by analyzing the tradition shape through direct observation, because the researcher is an active participant as native Acehnese and live among them. Furthermore, document review is done on the tradition. The results showed that meugang is one of the practices of values existing in Islam. This tradition is used as a means of religious teaching practice, such as anyone who likes to welcome Ramadan will be prevented from the fire of hell. This is indicated by eating meat as a form of pleasure of Acehnese people, as well as holding a feast expecting reward from food or alms. This tradition has been inherent in Aceh, so this tradition is like recommended in religion, it operates as a part of religion, and as if it is a compulsory ordered by religion.
\end{abstract}

Meugang adalah tradisi yang dilestarikan masyarakat Aceh sampai saat ini. Meugang diadakan pada saat menyambut bulan Ramadhan, hari raya Idul Fitri dan Idul Adha. Meugang merupakan wujud dari sebuah tafsir agama yang diamalkan dalam bentuk budaya masyarakat Aceh. Bagaimana tradisi meugang dalam masyarakat Aceh? Mengapa budaya meugang diyakini sebagai bagian dari agama dan beroperasi sebagai tafsir agama dalam kehidupan masyarakat Aceh? Penelitian ini menJawabnya dengan menganalisis bentuk tradisi meugang, melalui observasi langsung, karena peneliti adalah partisipan aktif sebagai orang 
Aceh asli dan hidup ditengah-tengah masyarakat. Selanjutnya juga dilakukan telaah dokumen yang berhubungan dengan tradisi meugang. Hasil penelitian menunjukkan bahwa meugang merupakan salah satu praktek dari nilai-nilai dalam agama Islam. Tradisi ini dijadikan sarana pengamalan ajaran agama, seperti barang siapa yang senang menyambut bulan Ramadhan, maka Allah akan mengharamkan tubuhnya dari api neraka. Hal ini ditunjukkan dengan makan daging sebagai bentuk senangnya orang Aceh, serta mengadakan kenduri mengharapkan pahala dari kenduri atau sedekah makanannya. Tradisi ini telah melekat dalam diri masyarakat Aceh, sehingga tradisi ini seolah-olah adalah ajaran agama yang sangat dianjurkan, beroperasi menjadi bagian dari agama, dan seakan-akan menjadi kewajiban yang diperintahkan oleh agama.

Keywords: meugang, religious interpretations, culture

\section{Pendahuluan}

Meungang (bahasa Aceh) merupakan salah satu tradisi yang masih dilestarikan di Aceh. Meugang atau sebagian menyebutnya ma'meugang adalah sebuah tradisi makan daging pada saat sebelum memulai puasa Ramadhan, lebaran Idul fitri dan lebaran Idul Adha. Tradisi ini diyakini sebagai suatu hal yang sangat penting dan tidak boleh ditinggalkan bagi masyarakat Aceh. Praktek perayaan meugang ini dirayakan oleh semua lapisan masyarakat, baik di desa maupun di kota. Sehingga momen ini tidak ingin dilewatkan oleh siapapun. Di Jawa, khususnya Jawa Timur dan Jawa Tengah, meugang ini serupa dengan trdisi megengan (bahasa Jawa), yaitu upacara slametan sederhana, untuk menandai akan masuknya bulan puasa yang diyakini sebagai bulan yang suci dan khusus (Nursyam, 2014: http://nursyam.uinsby.ac.id). Megengan ini juga dikenal dengan ruwah, asal kata dari arwah. Umat Islam di Jawa pada hari tersebut biasanya mengunjungi kuburan dan mengadakan tahlilan dan doa bersama untuk para arwah. Makanan yang terkenal dan mesti disediakan ketika megengan adalah apem (Geertz, 1976: 78).

Selain dianggap sebagai salah satu bagian agama yang mesti dilaksanakan, Perayaan meugang ini juga menjadi momen penting bagi keluarga, khususnya orang tua untuk berkumpul dengan keluarga. Biasanya pada hari meugang tersebut, anak dan sanak saudara yang merantau atau telah berkeluarga dan tinggal ditempat yang jauh, mereka akan pulang dan berkumpul pada hari meugang tersebut. Tidak ada perayaan yang sangat spesial dalam perayaan Meugang tersebut. Acara intinya adalah makan daging yang telah dimasak dengan bermacam masakan secara bersama-sama. Di beberapa tempat, masakan daging ini berbeda-beda sesuai dengan khas daerahnya sendiri. Di Pidie, 
Bireun, Aceh Utara dan beberapa daerah lain mereka lebih suka memasak kari atau sop daging, di Aceh Besar, mereka lebih terkesan apabila pada hari meugang tersebut memasak daging asam keueung dan sie reuboh (daging yang dimasak dengan cuka), walaupun nantinya juga ditambah dengan sop daging atau reundang (masakan daging rendang).

Selain daging, juga terdapat beberapa makanan yang sering disediakan kusus pada hari meugang, seperti tape (makanan dari ketan yang telah diprementasikan), leumang (makanan dari ketan yang dimasukkan dalam bambu, kemudian dimasak dengan cara dipanggang menggunakan api yang besar), serta timpan (makanan khas Aceh, dibuat dari tepung dan dibalut dengan daun pisang muda).

Pada perayaan meugang ini, juga diundang beberapa anak yatim ke rumah untuk makan. Hal ini tidak dilakukan oleh semua orang, hanya beberapa orang saja. Diperkirakan mereka adalah orang yang mampu dan memiliki pengetahuan agama yang baik. Sebagian besar masyarakat melakukan perayaan meugang hanya dengan memakan daging bersama keluarga dan sanak saudaranya sendiri.

Tradisi ini ditentang oleh kaum puritan dan dianggap sebagai budaya sinkretis. Puritan adalah kelompok yang berusaha melakukan pemurnian syariat, melarang aktivitas agama yang berbentuk suatu penyimpangan keyakinan Islam, dengan cara menegakkan gerakan menolak takhayul, bid'ah, dan khurafat. Kelompok yang lebih identik dengan ajaran ini di Indonesia adalah Muhammaddiyah. Sedangkan sinkretis adalah gambaran untuk kelompok Islam yang menerima budaya lokal menjadi budaya Islam, atau keduanya mengalami percampuran, budaya sinkretis masih melestarikan slametan, tahlilan, yasinan, dan lain-lain (Sutiyono, 2010: 5).

Akan tetapi, tidak sedikit mereka yang berpaham puritan juga merayakan meugang. Bagi mereka ini sudah menjadi suatu hal yang boleh dikerjakan, tanpa mengurangi kemurnian syariat. Sebagian mereka menganggap bahwa ini dilakukan untuk menghindari ketidakharmonisan dalam masyarakat. Oleh masyarakat Aceh, perayaan meugang ini dianggap penting karena dianggap merupakan bagian dari agama, akan tetapi sebagian masyarakat yang lain menganggapnya hanya sebagai adat istiadat yang boleh ditinggalkan. Dari kedua jenis alasan pentingnya perayaan meugang tersebut, alasan yang pertama lebih banyak diyakini oleh masyarakat. Dari sisi lain, dalam adat istiadat atau budaya Aceh, nilai-nilai Islam senantiasa menyatu dengan berbagai budaya di Aceh, seperti peusijuek, perkawinan, dan lain-lain (Marzuki, 2011: 133). 
Oleh karena itu, penelitian ini hendak mengetahui bagaimana tradisi meugang dalam masyrakat Aceh? mengapa budaya meugang ini diyakini sebagai bagian dari agama dan beroperasi sebagai tafsir agama dalam kehidupan masyarakat Aceh? Pertanyaan tersebut akan diJawab dengan menggunakan metode observasi langsung, karena peneliti adalah partisipant aktif sebagai orang Aceh asli dan hidup ditengah-tengah masyarakat, selanjutnya juga dilakukan telaah dokumen yang berhubungan dengan tradisi meugang di Aceh. Sebuah tradisi yang telah menjadi kebudayaan Islam pada dasarnya merupakan wujud dari tafsir agama yang telah diimplementasikan dalam masyarakat. Hal tersebut, selain memudahkan mayarakat dalam memahami agama, juga bertujuan mengeratkan ikatan agama dan masyarakat dalam kehidupan.

\section{Tafsir Agama dalam Budaya}

Agama dan budaya memiliki hubungan yang sangat dekat, bahkan sebagian agama merupakan hasil budaya. Agama yang bukan hasil budaya disebut dengan agama samawi (langit), sedangkan agama budaya disebut agama ardhi (bumi). Oleh karena itu agama samawi bukan merupakan produk budaya. Semua agama samawi tumbuh dan berkembang dalam masyarakat yang memiliki kebudayaan yang berbeda-beda. Sehingga tidak jarang agama samawi membaur ke dalam budaya suatu masyarakat.

Agama Islam sebagai salah satu agama samawi, merupakan agama yang sangat elastis dan mudah berkembang dimanapun. Oleh karena itu dengan mudah dapat ditemukan adanya Islam India, Islam Maroko, Islam Afrika dan Islam Indonesia, karena Islam ketika masuk dalam suatu masyarakat maka Islam menjadi bagian dari kehidupan masyarakat tersebut (Wood word, 2006: hlm).

Terdapat 2 (dua) hal yang perlu diketahui apabila Islam dikaitkan dengan budaya, yaitu Islam sebagai konsepsi sosial budaya, dan Islam sebagai realitas budaya. Islam sebagai konsepsi budaya disebut great tradition (tradisi besar), sedangkan Islam sebagai realitas budaya disebut little tradition (tradisi kecil) atau local tradition. (Koentjaraningrat, 1980: 170).

Tradisi besar merupakan dokrin-dokrin Islam yang permanen, atau dapat berupa interpretasi yang melekat pada ajaran dasar. Dokrin-dokrin ini tercakup dalam wilayah keimanan dan hukum syariah yang menjadi pola pikir dan dasar bertindak bagi umat Islam. Tradisi kecil merupakan kawasankawasan yang berada dalam Islam (great tradition). Tradisi lokal ini mencakup unsur-unsur yang terkandung di dalam pengertian budaya yang meliputi konsep 
atau norma, aktivitas serta tindakan manusia, dan berupa karya-karya yang dihasilkan masyarakat.

Islam sebagai agama samawi bukanlah produk dari budaya, akan tetapi Islam justru membawa budaya baru dalam masyarakat, sehingga muncul apa yang disebut dengan budaya Islam. Proses terciptanya budaya Islam dapat terjadi melalui beberapa macam, diantaranya adalah melalui asimilasi dan akulturasi. Asimilasi dan Akulturasi budaya terjadi sangat lambat dan sangat pelan, membutuhkan waktu yang lama untuk menghasilkan sebuah budaya baru. Terciptanya budaya baru dari proses asimilasi dan akulturasi ini juga dipengaruhi oleh tafsir agama yang melibatkan budaya. Banyak sekali ditemukan inti dari budaya sebuah daerah atau bangsa merupakan tafsir dari agama dalam budaya. Seperti maraknya budaya di Indonesia dalam bentuk kenduri dan hajatan, ini merupakan tafsir agama yang diwujudkan dalam kehidupan masyarakat melalui praktek budaya.

Tafsir agama merupakan interpretasi dari ajaran agama yang diwujudkan dalam praktek keagamaan. Tafsir agama dalam budaya dapat dikatakan merupakan jenis tafsir bil hal yang merupakan hasil dari pemahaman atau interpretasi ajaran agama, baik yang berasal dari al Quran maupun Hadits. Sejak awal masa penyebaran Islam, jenis tafsir agama ini sangat efektif dalam menyebarkan ajaran Islam, terutama di Nusantara yang sulit memahami langsung tafsir dari al Quran dan Hadits. Keadaan ini menyebabkan para penyiar Islam, Ulama pada masa itu mengajarkan ajaran Islam menggunakan tafsir dalam kerangka budaya.

\section{Kerangka Teori}

Melalui bagan di atas, dapat dipahami bahwa tafsir dalam agama dapat dikelompokkan juga kepada tafsir bil hal, yaitu bagaimana tafsir agama diterjemahkan atau diinterpretasikan dalam bentuk budaya atau perilaku dalam kehidupan sehari-hari. Hal tersebut untuk memudahkan masyarakat yang awam dalam memahami ajaran Islam. Fenomena budaya tidak dapat dilihat melalui pedekatan normatif, akan tetapi membutuhkan bantuan dari pendekatan budaya atau antropologi dalam memahaminya. 


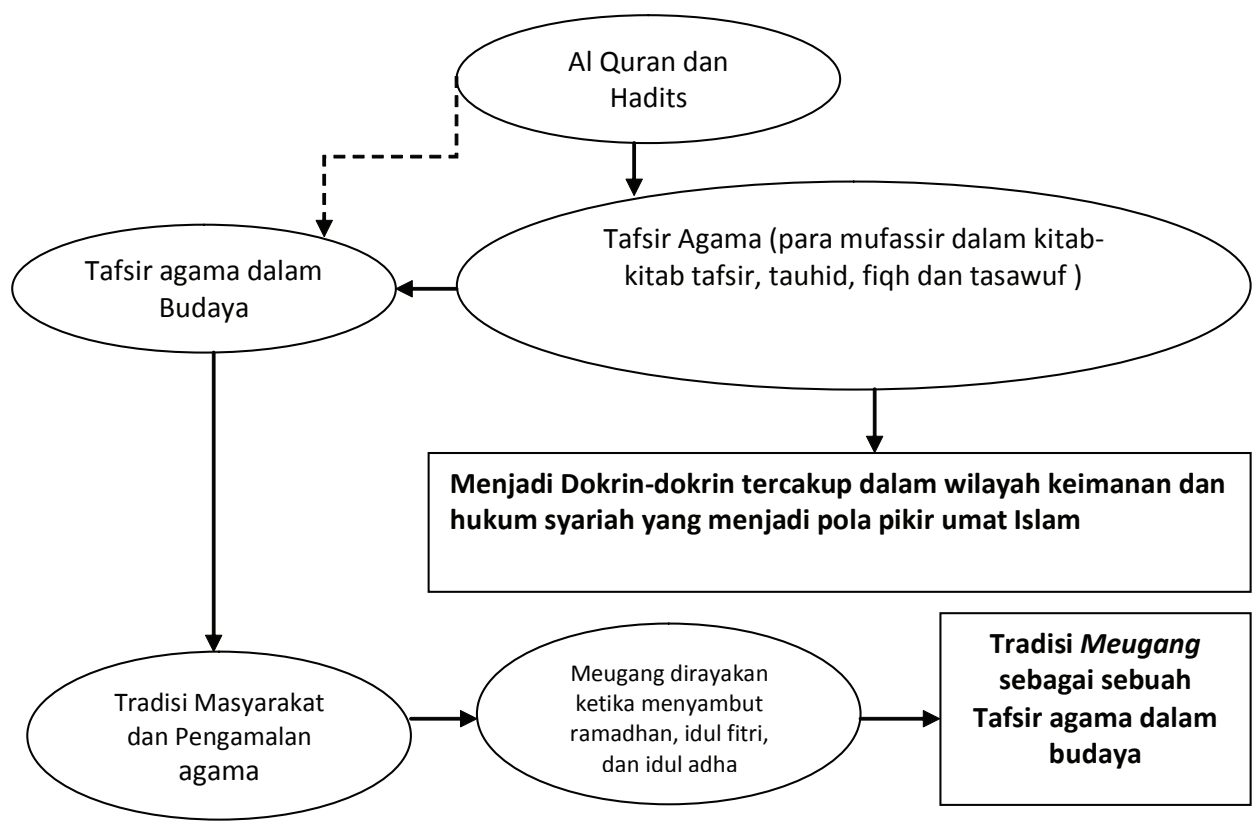

\section{Tradisi Meugang dalam Masyarakat Aceh}

Sebagai salah satu daerah yang mayoritas muslim, Aceh memiliki banyak ragam budaya Islam yang masih dilestarikan sampai saat ini. Banyak di antara budaya-budaya tersebut merupakan implementasi dari nilai-nilai agama normatif, kemudian diwujudkan dalam bentuk budaya atau tradisi yang melekat dalam kehidupan masyarakat. Hal tersebut merupakan salah satu upaya dari para ulama dalam melestarikan nilai-nilai agama dalam kehidupan masyarakat, agar masyarakat selalu dalam ikatan agama meskipun dalam urusan duniawi. Tindakan ini merupakan salah satu langkah para ulama dalam menghindarkan masyarakatnya agar tidak terjerumus kedalam pemahaman sekuler.

Meugang merupakan salah satu tradisi dalam masyarakat Aceh yang masih dilestarikan oleh berbagai lapisan masyarakat, baik di pedesaan maupun di perkotaan. Kata meugang juga sering disebut dengan kata mameumang, ma'meugang ketiga istilah sering diucapkan oleh masyarakat Aceh (Iskandar, 2010: 47). Tradisi meugang ini dilaksanakan oleh berbagai kalangan, baik fakir, miskin, apalagi orang kaya. Tentunya bentuk dari pelaksanaan meugang ini berbeda-beda antara orang yang mampu dengan orang yang tidak mampu. Walaupun demikian, yang diinginkan oleh mereka yang melaksanakan meugang ini adalah ikut serta merayakan meugang walaupun semampunya saja. 
Tidak ditemukan referensi yang sangat menyakinkan dalam lintasan sejarah, siapa dan kapan pertama sekali tradisi meugang ini dilakukan. Ali Hasjimy menyebutkan bahwa tradisi ini sudah dimulai sejak masa kerajaan Aceh Darussalam. Tradisi meugang ini dilaksanakan oleh kerajaan di istana yang dihadiri oleh para sultan, menteri, para pembesar kerajaan serta Ulama (Iskandar, 2010: 48). Pada hari itu, raja memerintahkan kepada Balai Fakir, yaitu badan yang menangani fakir miskin dan dhuafa untuk membagikan daging, pakian dan beras kepada fakir miskin dan kaum dhua'fa. Biaya ini semuanya ditanggung oleh bendahara Silatu Rahim, yaitu lembaga yang menangani hubungan negara dan rakyat di Kerajaan Aceh Darussalam (Hasjimy, 1983: 151). Denys Lombard dalam bukunya "Kerajaan Aceh Zaman Sultan Iskandar Muda" juga menyebutkan adanya upacara meugang di Kerajaan Aceh Darussalam, bahkan menurutnya, di sana ada semacam peletakan karangan bunga di makam para sultan (Lombard, 2007: 204-205)

Ada yang menyebutkan bahwa perayaan meugang ini dilaksanakan oleh Sultan Iskandar Muda sebagai wujud rasa syukur raja serta menyambut datangnya bulan Ramadhan, sehingga dipotonglah lembu atau kerbau, kemudian dagingnya dibagi-bagikan kepada rakyat. Setelah Perang dan masuk penjajah Belanda, tradisi tersebut juga masih dilakukan, akan tetapi dikoordinir oleh para hulubalang sebagai penguasa wilayah. Begitulah, sampai saat ini tradisi meugang terus dilestarikan dan dilaksanakan oleh berbagai kalangan masyrakat dalam kondisi apapun (Iskandar, 2010: 49).

Dalam karya monumentalnya, "Aceh di Mata Kolonialis", C. Snouck Hurgronje menyebutkan bahwa,

"Maksud persiapan selama tiga hari itu terutama supaya tersedia cukup bekal untuk setiap kali berbuka puasa di waktu matahari terbenam dan makan pagi (sahur)sebelum matahari terbit. Juga untuk menjaga supaya orang berpuasa sedapat mungkin tidak perlu pergi berbelanja. Bukankah mereka yang berpuasa terlalu letih untuk memberikan cukup perhatian berdagang di siang hari, sehingga pasar-pasar hampir sepi selama 30 hari berpuasa"

Makan dua kali yang dibolehkan dalam bulan puasa, yakni malam dan sebelum subuh, sebanyak mungkin mengandung gizi sehingga memberikan cukup tenaga untuk menunaikan perintah agama dengan baik. Disamping itu dipilih makanan lezat yang tidak setipa hari disajikan, kalau tidak nafsu makian akan hilang dan malah dapat mendatangkan penyakit. Ikan kering yang merupakan makanan sehari-hari di Aceh, selama bulan puasa diganti dengan daging, yang biasanya jarang dimasak dan demikian dianggap makanan 
yang lezat" (Hurgronje, 1985: 293).

Keterangan dari C. Snouck Hurgronje menunjukkan bahwa dahulunya meugang dikenal dengan tiga hari, akan tetapi setelah adanya kesepakatan dari para ulama di Aceh dan Indonesia pada umumnya untuk menggunakan metode rukyah dalam penentuan 1 Ramadhan, maka meugang hanya dikenal satu hari saja, yaitu satu hari sebelum 1 Ramadhan, hanya sebagian orang ada yang memilih merayakan meugang sejak dua hari sebelum Ramadhan. Dalam karyanya yang lain, C. Snouck Hugronje menyebutkan bahwa daging meugang juga digunakan untuk persediaan makanan pada saat perang, tentunya dengan menggunakan metode pengawetan terhadap daging yang dipotong pada saat meugang (Hurgronje, 1997: 175)

Tradisi meugang yang dilaksanakan sekarang adalah pada saat $\mathrm{H}-1$ atau H-2 Ramadhan, serta H-1 dan H-2 Hari raya Idul Fitri dan Idul Adha. Pada dasarnya meugang hanya dilaksanakan pada satu hari sebelum tanggal Ramadhan, Idul Fitri dan Idul Adha. Mengapa kemudian ada perayaan meugang pada H-2? Hal ini dikarenakan banyak dari kalangan pegawai negeri Sipil (PNS) atau pegawai kantor lainnya yang membagikan daging atau sepakat untuk memotong hewan seperti lembu dan kerbau untuk meugang pada satu hari sebelumnya. Di tingkat pedesaan, yang merayakan meugang pada dua hari sebelum adalah para guru dan beberapa PNS lainnya, namun demikian mereka juga ikut membeli daging juga pada hari berikutnya bersama masyarakat umumnya. Alasan lain adalah karena sering terjadi perbedaan pendapat di kalangan ulama di Aceh dan Indonesia pada umumya, terutama antara muhammadiyyah dan NU. Menurut C. Snochk Horogje hal seperti ini telah terjadi sejak lama dalam masyarakat Aceh, ia menyebutkan bahwa sebagian orang mengikuti model perhitungan yang telah menjadi kebiasaan di ibu kota (Koetaraja atau Banda Aceh), dan sebagian lagi mengikuti cara rukyah. Hal ini mempengaruhi jumlah dari yang dinamakan hari meugang, yang seharusnya hanya satu atau dua hari sebelum meugang, menjadi tiga hari sebelum meugang, yaitu pada 27, 28, dan 29 Sya'ban atau pada 28, 29, 30 Sya'ban (Hurgronje, 1985: 293).

Dalam memaknai meugang ini, masyarakat Aceh dapat dikategorikan ke dalam beberapa macam, pertama tingkatan para orang 'alim atau para Tengku, meugang dalam pandangan mereka adalah hari dimana umat Islam harus merasa senang dengan akan masuknya bulan Ramadhan, bulan umat Islam diwajibkan berpuasa. Mereka ini akan memperbanyak bersedekah, saling maaf memaafkan antara sesama, demi membersihkan diri ketika memasuki bulan Ramadhan. 
Sebelum memasuki bulan puasa, umat Islam harus mempersiapkan diri mereka, baik lahir maupun batin. Secara lahir, mereka membersihkan rumah dan meunasah atau masjid, serta memanfaatkan daging meugang sebagai makanan untuk sahur dan berbuka selama berpuasa. Secara batin, mereka menyiapkan diri agar mampu untuk beribadah pada bulan puasa, karena bulan ramadhan adalah bulan yang lebih baik dari pada seribu bulan. Orang yang beribadah di dalamnya akan dibalas berkali lipat. Pada tingkat kedua, meugang merupakan hari mempersiapkan diri secara lahir saja, seperti menyediakan makanan untuk sahur dan berbuka dalam bulan puasa, membeli pakaian muslim yang baru, sajadah, rumah dan meunasah dibersihkan.

Intinya, menurut mereka, pada bulan Ramadhan harus nampak bersih dan siap secara lahir, sehingga mereka lebih merasa puas apabila hal-hal tersebut telah terpenuhi, tanpa memahami makna dan pahala dari puasa. Pada tingkatan ketiga adalah mereka yang memaknai meugang sebagai hari berpuas-puasan, yaitu pada hari itu mereka makan seenak-enaknya dan sekenyang-kenyangnya, bagi perokok akan merokok sepuas-puasnya pada hari tersebut. Daging meugang yang disediakan dimaknai sebagai makanan yang harus dihabiskan pada hari itu, karena besok ketika puasa tidak dibolehkan lagi untuk makan pada siang hari.

Tata cara masyarakat dalam merayakan meugang berbeda-beda, terutama dalam upaya menyediakan daging untuk mengang. Setidaknya ada 4 (empat) model yang dipraktekkan oleh masyarakat Aceh dalam mengadakan daging untuk meugang. Pertama, acara meuripee, yaitu masyarakat sepakat untuk mengumpulkan sejumlah uang dan membeli hewan sembelihan (lembu atau kerbau), kemudian nantinya daging akan dibagikan sesuai dengan jumlah orang yang ikut mengumpulkan uang atau meuripee tersebut. Cara seperti ini banyak dilakukan oleh masyarakat yang kebanyakan sudah mapan dan berpenghasilan tetap, sehingga diantara mereka bisa melunasinya dalam beberapa kali. Model seperti ini juga dilakukan oleh para guru dan karyawan di perkantoran, baik negeri maupun swasta, serta beberapa organisasi dan perkumpulan juga mengambil model ini.

Kedua, membeli pada agen yang akan menyembelih pada hari meugang, mereka ini beberapa minggu sebelum meugang melakukan penjajakan ke rumah-rumah untuk menawarkan daging yang nanti akan disembelih pada hari meugang. Setelah dapat berapa orang yang mengambil daging, maka ditentukanlah berapa lembu yang akan disembelih. Pada hari meugang orang yang telah dicatat namanya datang ke tempat yang telah ditentukan dimana 
penyembelihan dilakukan, mereka mengambil daging sesuai pesanan. Daging yang diberikan bukan dalam ukuran kilogram, akan tetapi dalam ukuran tumpok, istilah tumpok dalam bahasa Aceh adalah daging yang ditumpuk dan dicampur muai dari daging, tulang, serta kulit. Semua mendapatkan jatah yang sama, walaupun ada sebagian yang lebih dan kurang dalam pembagiannya, tetapi hal tersebut tidak dipermasalahkan, karena memang daging tersebut dikatakan sie tumpok (daging tumpuk).

Ketiga, membeli di pasar, karena dua hari sebelum Ramadhan, Idul Fitri, dan Idul Adha, pedagang daging akan membanjiri pasar-pasar. Dimanamana daging dijual, kebanyakan adalah daging lembu dan kerbau. Di kota, satu pedagang dapat menghabiskan dua sampai tiga lembu dalam satu hari, tetapi kebanyakan mereka menghabiskan hanya satu lembu untuk satu hari, terutama di pasar-pasar pedesaan, karena masyarakat masih banyak yang mengambil daging tumpok. Harga daging di pasar pada saat meugang naik dari biasanya hingga mencapai 50\% dari harga hari biasa, biarpun demikian masyarakat tetap membelinya demi untuk mengang di hari tersebut.

Ada beberapa kalangan yang membeli daging di pasar daging musiman ini, yaitu golongan tua, dewasa, pemuda, dan pengantian baru (Iskandar, 2010: 50). Setiap golongan ini memiliki latar belakang yang berbeda ketika membeli daging, golongan tua membuktikan dirinya sebagai orang tua yang bertanggung Jawab terhadap keluarganya. Golongan dewasa yang sebagian mereka masih menempati rumah mertua adalah kesempatan untuk membuktikan diri sebagai kepala keluarga yang bertanggung Jawab serta memiliki harga diri. Golongan pemuda biasanya mereka yang telah memiliki pekerjaan atau mereka yang pulang dari rantau, hari meugang mereka membuktikan dan mengabdikan diri mereka kepada orang tua dengan membeli daging meugang untuk keluarganya.

Golongan terakhir adalah pengantian baru yaitu laki-laki yang baru menikah dan tinggal di rumah istrinya, biasanya mereka akan membeli daging meugang dengan jumlah yang banyak, bahkan pada era 80-an sampai 90-an, membeli kepala kerbau dan membawa pulang ke rumah mertua merupakan suatu kehebatan tersendiri bagi pengantin baru ini. Oleh karena itu, tidak heran apabila di suatu rumah kelebihan daging, apalagi di rumah orang tua yang memiliki anak yang banyak dan mampu, merupakan suatu kehormatan apabila pada hari meugang dapat membawa pulang satu kilo daging untuk orang tuanya.

el Harakah Vol.16 No.2 Tahun 2014 
Keempat, sebagian masyarakat tidak memilih daging lembu atau kerbau untuk meugang, akan tetapi mereka hanya menyembelih ayam atau bebek yang dipelihara sendiri. Terkadang ada juga yang membelinya dari tetangga yang memelihara ayam atau bebek. Mereka ini kebanyakan termasuk masyarakat kurang mampu, akan tetapi mereka tetap merayakan meugang, walaupun tidak makan daging merah. Di sisi lain, memiliki dan menyembelih ayam dan bebek bagi orang kampung di Aceh bukanlah suatu kebanggaan, bahkan menyembelih ayam atau bebek adalah alternatif apabila tidak ada ikan. Ayam dan bebek kebanyakan merupakan peliharaan tetap di setiap rumah penduduk kampung, sehingga mereka yang kurang mampu memilih menyembelih ayam atau bebek saja, karena tidak ada uang untuk membeli daging merah. Kalangan ini adalah mereka yang meerayakan meugang dengan sangat sederhana, model seperti ini dilakukan hingga mereka yang tergolong fakir miskin sekalipun, mereka akan berusaha untuk menyembelih satu ayam atau bebek pada hari meugang tersebut.

Pemerintah Aceh ikut serta dalam mengawasi tradisi meugang ini, terutama dalam memastikan ketersedian daging meugang di pasar dan harganya tidak melonjak naik terlalu tinggi dari harga biasanya. Momen meugang ini juga kesempatan bagi para pimpinan di daerah, seperti gubernur dan bupati untuk melakukan blusukan ke pasar-pasar. Pad hari meugang ini, barangbarang mengalami kenaikan harga dari hari-hari biasanya. Selain memang dipengaruhi oleh bulan puasa dan lebaran, adanya tradisi meugang juga mempengaruhi konsumsi masyarakat menjadi tinggi. Kebutuhan barang yang tinggi dan ketersediaan yang terbatas menyebabkan kenaikan harga barang di hari meugang.

Pada dua hari sebelum Ramadhan, Idul Fitri, dan Idul Adha orang-orang sudah mulai memasak daging, terutama kalangan pegawai karena mereka sudah terlebih dahulu mendapatakan daging. Hari petama meugang ini disebut meugang phon (meugang pertama), selanjutnya esok hari adalah meugang kedua. Inti meugang adalah meugang pada satu hari sebelum Ramadhan, Idul Fitri dan Adul Adha. Meugang pertama sedikit yang merayakannya, biasanya adalah mereka-mereka yang ikut meuripee di kantor atau mereka yang mendapat jatah/hadiah daging dari kantor atau sekolah bagi guru, baik negeri maupun swasta.

Jenis atau menu masakan berbeda-beda antara satu daerah dengan daerah lainnya. Bahkan antara satu rumah dengan rumah lainnya, akan tetapi ini kebanyakan terjadi di kota-kota karena mereka adalah pendatang dari 
berbagai daerah, sehingga mereka memasak sesuai kebiasaan dari daerahnya masing-masing. Sekarang banyak juga yang memasak masakan modern yang sebelumnya tidak dikenal di Aceh, seperti stik, semur, rendang, sate, dan lain-lain. Di perkotaan, jenis masakan tidak lagi menjadi perhatian, intinya mereka memuaskan diri dengan makan daging pada hari meugang tersebut. Sebaliknya di daerah-daerah, masakan memiliki khas masing-masing, apabila terjadi pergeseran dapat dikatakan hanya sedikit karena mengikuti zaman modern.

Lain lubuk lain ikannya, mungkin pepatah ini juga dapat digunakan untuk menganalogikan jenis dan rasa masakan yang berbeda-beda sesuai dengan daerahnya. Kabupaten Aceh Besar dan sebagian kota madya Banda Aceh sangat terkenal dengan masakan kuah beulangong, yaitu masakan daging yang ditambah buah nangka muda yang telah dicincang dimasak dalam kuali besar, menggunakan api yang besar. Kuah beulangong ini menjadi lambang masakan di Aceh Besar dalam berbagai acara resmi, seperti pesta perkawinan, khitanan, kenduri maulid, dan lain-lain, akan tetapi tidak dimasak pada hari meugang. Pada hari meugang, masakan yang terkenal di Aceh Besar adalah Asam Keueung dan Sie Ruboh. Asam keueung adalah masakan daging yang menggunakan bumbu menyerupai masakan daging cincang padang, akan tetapi khasnya masakan asam keueung ini adalah diberi cuka untuk rasa asam, terkadang bagi yang kurang menyukai asamnya cuka, ditarok jeruk perut sebagai bahan untuk rasa asamnya. Sie reuboh adalah daging yang direbus dengan bumbu-bumbu rempah,

Di Kabupaten Pidie, Bireun, Aceh Utara, Lhokseumawe, dan Langsa pada hari meugang, daging dimasak dengan masakan khas daerah dan telah dikenal luas di Indonesia bahkan internasional, yaitu masakan kari. Jenis kari ini berbeda-beda antara satu daerah dengan daerah lain. Kari di Aceh memiliki perbedaan dengan kari India, walaupun rasanya sama-sama enak. Di samping masakan kari, mereka juga menambah beberapa masakan lain, itupun tergantung sedikit banyaknya daging yang ada, seperti masak merah, masak putih, sop, rendang, dan lain-lain, sesuai dengan selera masing-masing.

Di kabupaten Pidie ada kebiasaan touet leumang (bakar leumang), yaitu jenis makanan dari beras ketan yang dicampur dengan santan, kemudian dimasukkan ke dalam bambu bulat, dan dibakar menggunakan api yang besar dengan disandarkan berbaris di pinggir api. Touet leumang ini biasanya dilakukan bersama tetangga dekat juga saudara dekat. Persiapan dilakukan dari pagi, mulai dari menyiapakan bambu sampai dengan memasukkan 
beras ke dalam bambu. Proses pembakarana memerlukan waktu yang lama, biasanya sampai larut malam baru matang dan dapat diangkat dari tempat pembakaran. Leumang ini merupakan salah satu masakan khas Aceh yang bisa didapatkan hampir di semua daerah di Aceh, di bulan puasa sangat mudah mendapatkannya.

Di kabupaten Nagan Raya, Aceh Barat (Meulaboh), Aceh Barat Daya, dan Aceh Selatan juga memiliki masakan yang berbeda dengan daerah lainnya. Masakan daging meugang biasanya dibuat gulai merah, disamping masakan-masakan lainnya. Ciri khas masakan dari wilayah barat-selatan ini adalah rasa pedas, menyerupai masakan Padang, Sumatra Barat. Hal ini tidak mengherankan, karena memang sebagaian besar orang dari Aceh selatan adalah berketurunan Padang, sehingga bahasa mereka yang dikenal dengan bahasa Jamee (tamu) sangat mirip dengan bahasa Padang. Sudah menjadi kebiasaan disana, selain masakan daging, mereka juga menyediakan tapee dan leupeek atau timpan adalah sebuah kewajiban ketika hari mengang, sebagai pelengkap setelah menyantap daging.

Selain itu, ada sebuah tradisi yang unik yang masih dilestarikan oleh masyarakat barat-selatan ini, yaitu tradisi meuramien (rekreasi) ke tempat-tempat rekreasi pada saat meugang, seperti sungai dan ke laut dengan membawa masakan yang telah dimasak. Pada umumnya yang ikut rekreasi ini adalah para sanak saudara berkumpul untuk makan bersama. Di sisi lain ketika mengang bulan puasa, hal ini merupakan kegiatan menyegarkan diri untuk memasuki bulan puasa, yang tidak dibolehkan untuk berekreasi, riya dan bersenang-senang seperti hari meugang tersebut.

Pada hari meugang ini, anak-anak yatim biasanya mendapat beberapa undangan untuk makan di beberapa rumah. Selain anak yatim, orang fakir miskin juga biasanya mendapatkan undangan dari orang-orang yang memiliki kemudahan. Mengundang anak yatim ini merupakan inisiatif dari masingmasing orang apabila ia mampu. Tidak jarang, setelah makan, para anak yatim ini juga diberikan sedekah uang, sekedarnya.

Meugang di Aceh merupakan tradisi yang sudah melekat dalam kehidupan masyarakat Aceh. Setiap masyarakat Aceh pasti mengetahui istilah meugang ini. Di samping sebagai tradisi, meugang ini merupakan kesempatan untuk berkumpul seperti istilah makan besar dalam tradisi masyarakat Tionghoa. Pada kesempatan ini, anggota keluarga yang tinggal jauh akan pulang ke rumah orang tuanya, dan anak-anak yang merantau juga pulang kerumah. Meugang mempererat hubungan kekeluargaan dan mengokohkan silaturahmi 
keluarga. Tradisi meugang adalah pengamalan nilai-nilai Islam dalam kehidupan sehari-hari. Oleh karena itu, tradisi meugang ini dapat dikatakan merupakan sebuah bentuk dari tafsir agama yang diaplikasikan dalam bentuk budaya atau tradisi.

\section{Tafsir Agama dalam Tradisi Meugang}

Tradisi meugang bukanlah murni ajaran Islam, akan tetapi ia merupakan sebuah aplikasi pengamalan Islam dalam bentuk budaya. Ruh dari tradisi mengang ini adalah nilai-nilai keislaman yang ditanamkan didalamnya. Melaksanakan tradisi meugang bukanlah sebuah kewajiban, akan tetapi merupakan sebuah keharusan bagi orang Aceh, yang mesti dilaksanakan. Untuk meyakinkan bahwa tradisi meugang ini adalah sebuah tafsir agama, kita dapat melihat beberapa hal yang melatar belakangi adanya tradisi meugang ini, yaitu (1) Meugang dilaksanakan menyambut bulan puasa, Idul Fitri dan Idul Adha. (2) Meugang dijadikan momentum untuk bersedekah.

Latar belakang pertama dilaksanakannya meugang adalah untuk meyambut masuknya bulan puasa, Idul Fitri dan Idul Adha. Melihat ketiga momen penting tersebut, sudah dapat diketahui secara pasti bahwa agama sangat kuat melatarbelakangi perayaan meugang. Ketiga momen penting tersebut tidak akan dilewatkan oleh siapapun yang beragama Islam, walaupun mereka yang beragama "Islam KTP".

Bulan Ramadhan merupakan satu bulan yang istimewa bagi umat Islam dalam dua belas bulan setahun. Banyak sekali Hadits yang menunjukkan tentang keistimewaan bulan ramadhan. Allah berfirman:

"Katakanlah: "Dengan kurnia Allah dan rahmat-Nya, hendaklah dengan itu mereka bergembira. Kurnia Allah dan rahmat-Nya itu adalah lebih baik dari apa yang mereka kumpulkan”. (QS. Yunus ayat 58).

Dalam kitab Durratun Nashihin disebutkan bahwa Rasulullah saw bersabda, "man fariha bi dukhuli ramadhan, harramallahu jasadahu 'alan nirani", yang artinya, "barang siapa yang senang dengan masuknya bulan ramadhan, Allah akan mengharamkan tubuhnya dari api neraka". Hadits ini dipahami bahwa siapa saja yang senang dengan masuknya bulan Ramadhan, maka ia akan mendapat jaminan dari Allah, tidak akan dimasukkan ke dalam neraka. Senang dapat diartikan dengan berbagai macam, tergantung orang yang menikmatinya. Makan daging merupakan salah satu bentuk kesenangan. Karena daging merupakan makanan yang terhitung mahal dan tidak mudah untuk dibeli oleh setiap orang. Sehingga makan daging dapat dikatakan 
merupakan salah satu ekspresi dari bentuk kesenangan suatu masyarakat. Makan daging pada satu hari sebelum Ramadhan merupakan bentuk rasa senang dari masyarakat Aceh dengan datangnya bulan Ramadhan. Bisa jadi, seseorang hanya makan daging pada hari meugang saja atau setahun hanya tiga kali makan daging, yaitu pada hari-hari meugang (Ramadhan, Idul Fitri dan Idul Adha).

Menyambut idul fitri dengan meugang juga menjadi tradisi masyarakat Aceh. Meugang idul fitri dapat dimaknai sebagai wujud rasa syukur umat Islam karena telah berhasil melaksankan ibadah puasa sebulan penuh, selanjutnya pada saat berbuka hari terakhir puasa mereka berbuka dengan menu daging meugang. Sehingga meugang Idul Fitri menjadi salah satu bentuk rasa syukur masyarakat Aceh atas keberhasilan melaksanakan puasa sebulan penuh. Sebagian masyarakat yang memilki keimanan dan ilmu agama yang rendah, kebanyakan mereka adalah dari kalangan pemuda, mereka tidak lagi berpuasa pada hari terakhir (hari meugang), atau mereka berpuasa, akan tetapi ketika daging sudah matang dan siap untuk dimakan, puasa langsung dibuka, padahal belum masuk waktu untuk berbuka puasa. Hal ini merupakan kebiasaan yang tidak bagus, tetapi sekarang hal tersebut sudah mulai hilang, seiring banyak ceramah-ceramah Teungku (ustadz) yang menyinggung masalah tersebut.

Dalam menyambut hari raya Idul Adha atau hari raya Kurban, masyarakat Aceh juga melaksanakan meugang. Meugang dilaksanakan ketika satu atau dua hari sebelum hari raya Idul Adha merupakan ekspresi rasa gembira masyarakat Aceh dalam merayakan Idul Adha. Masyarakat Aceh menyambut hari raya Idul Adha dengan sangat senang, karena idul adha merupakan salah satu hari raya besar dalam Islam. Pada dasarnya lebaran Idul Adha adalah lebaran bagi mereka yang telah melaksanakan ibadah haji, namun umat Islam diseluruh belahan dunia juga ikut bergembira dengan keberhasilan para jamaah haji setelah perjuang panjang menyelesaikan rangkaian ibadah haji.

Adanya meugang pada saat memasuki bulan Ramadhan, hari raya Idul Fitri dan Idul Adha juga memilik berbagai tujuan lain, selain hanya makan daging pada hari mengang tersebut. Meugang memasuki puasa misalnya, merupakan sebuah persiapan bagi orang-orang yang akan berpuasa untuk memasak daging dan disiapkan pada saat berpuasa, terutama untuk menu sahur, karena pada awal-awal puasa biasanya orang butuh gizi yang cukup, salah satunya adalah dengan cara makan daging. Meugang hari raya juga bertujuan untuk menyiapkan makanan dari daging meugang untuk menu hari lebaran, karena pada umumnya hari lebaran sanak saudara berkumpul 
untuk bersilaturahim. Setiap tamu yang datang, akan dipersilahkan untuk mencicipi makanan yang tersedia.

Latar belakang kedua adalah meugang dijadikan momentum untuk beramal saleh melalui sedekah. Bentuk sedekah dibagi ke dalam 2 (dua) macam, pertama yang bersedekah dengan daging untuk fakir miskin pada hari meugang tersebut. Fakir miskin, orang tua jompo, janda dan anak yatim diberikan daging atau datang ke tempat yang telah ditentukan untuk mengambilnya. Daging yang disedekahkan berkisar dari setengah kilogram sampai satu kilogram. Kedua adalah mereka yang bersedekah dengan memberi makan kepada fakir miskin, anak yatim, janda dan orang tua jompo. Daging yang sudah dimasak, serta ditambah dengan menu-menu lainnya dihidangkan untuk tamu yang diundang. Waktu undangan biasanya ketika makan siang atau makan malam. Tidak banyak jumlah undangan yang diundang, biasanya adalah anak-anak yatim terdekat di kampung masing-masing.

Melihat kedua latar belakang perayaan meugang oleh masyarakat Aceh, dapat diketahui bahwa meugang sangat berkaitan dengan agama Islam. Nilainilai Islam tertanam dalam perayaan meugang di Aceh. Apabila dilihat dalam kacamata budaya, meugang hanyalah sebuah tradisi yang tidak ada hubungannya dengan agama, akan tetapi apabila dikaitkan dengan konteks dan latar belakang perayaan meugang ini, maka tradisi meugang di Aceh dapat dikatakan adalah bagian dari pengamalan ajaran Islam. Hal tersebut dilatarbelakangi oleh kenyataan bahwa syariat Islam merupakan living of live bagi masyarakat Aceh yang diaplikasikan dalam aktivitas keseharian serta adat istiadatnya (Bustamam-Ahmad, 2013: 151).

Tidak terdapat dalil khusus yang berbentuk perintah dari agama untuk mengadakan meugang seperti yang dirayakan oleh orang Aceh. Inilah yang kemudian dibutuhkan tafsir agama dalam budaya untuk menganalisis fenomena meugang tersebut. Memahami fenomena budaya dalam masyarakat Islam perlu menggunakan tafsir agama dalam budaya. Sehingga ketika melihat sebuah budaya dalam Islam, tidak langsung melakukan klaim sesat atau bid'ah terhadap budaya tersebut.

Tafsir agama yang dimaksudkan dalam budaya meugang adalah pengamalan Hadits Nabi tentang menyambut bulan Ramadhan yang diaplikasikan dalam bentuk mengadakan tradisi meugang ketika memasuki bulan Ramadhan, Idul Fitri dan Idul Adha. Begitu juga, melalui tafsir agama dalam budaya dapat kita ketahui dari perayaan meugang bahwa nilai Islam yang menyuruh untuk berbuat baik dan bersedekah kepada yang membutuhkan dapat diaplikasikan melalui meugang. 
Kedua hal tersebut tidak akan kita ketahui, apabila hanya menggunakan kacamata normatif saja. Secara kacamata normatif, tradisi meugang adalah sebuah bid'ah atau hal yang sia-sia, karena tidak pernah dilakukan oleh Rasulullah saw, sehingga haram dikerjakan. Oleh karena itu, kontribusi tafsir agama dalam budaya sangat dibutuhkan untuk memahami berbagai budaya Islam yang ada di Indonesia. Hal ini sangat penting untuk menciptakan harmonisasi antara umat Islam, sehingga tidak terjadi saling salah menyalahkan, menganggap kelompoknya yang paling benar.

\section{Simpulan}

Meugang merupakan salah satu tradisi masyarakat Aceh yang dilaksanakan ketika menyambut bulan puasa, idul fitri dan idul adha. Meugang telah menjadi tradisi yang melekat dan menyatu dengan barbagai kalangan masyarakat di Aceh. Meugang sebagai sebuah tafsir agama dapat diketahui melalui hal-hal yang melatarbelakangi diadakannya tradisi tersebut dalam masyarakat Aceh. Ada 2 (dua) hal yang melatar belakangi adanya perayaan meugang di Aceh. Pertama, meugang dilaksanakan menyambut bulan puasa, Idul Fitri dan Idul Adha. Kedua, meugang dijadikan momentum untuk bersedekah.

Adanya latar belakang menyambut bulan puasa, Idul Fitri dan Idul Adha dalam perayaan meugang merupakan bentuk dari eratnya kaitan antara meugang dan ajaran agama Islam. Hendaklah seorang muslim senang dengan masuknya bulan Ramadhan, karena pada bulan tersebut Allah melipat gandakan semua amalan, bulan yang lebih baik dari seribu bulan. Bersedekah yang melatarbelakangi meugang juga menjadi fakta penting dibalik tradisi meugang, karena ajaran Islam sangat menganjurkan untuk bersedekah dan berbuat baik kepada orang lain.

Sehingga dapat diketahui dengan jelas, bawa meugang adalah bagian dari ajaran agama yang dijalankan atau diamalkan oleh masyarakat Aceh dalam bentuk budaya atau tradisi yang telah melekat. Meugang merupakan tafsir agama yang diwujudkan dalam budaya.

\section{Daftar Pustaka}

Ali Hasjmy, 1983. Kebudayaan Aceh dalam sejarah. Jakarta: Beuna

Horgronje, C. Snouck. 1985. Aceh di Mata Kolonialis. Jilid I, Jakarta: Suko Guru.

Hurgronje, C. Snouck. 1997. Aceh: Rakyat dan Adat Istiadatnya Jilid I. Jakarta: 
INIS.

Lombard, Denys. 2007. Kerajaan Aceh Zaman Sultan Iskandar Muda (1607-1636). Jakarta: Kepustakaan Populer Gramedia.

Iskandar. 2010. Perayaan Mameugang dalam Perspektif Hukum Islam. Laporan Penelitian Dosen. Lhokseumawe-Aceh: STAIN Malikusssaleh.

Marzuki. 2011. Tradisi Peusijuek dalam Masyarakat Aceh, Jurnal El-Harakah Vol. 13 No.2: 133-149.

Sutiyono. 2010. Benturan Budaya Islam: Puritan dan Sinkretisme. Jakarta: Kompas Media Nusantara.

Woodword, Mark K. 2006. Islam Jawa: Kesalehan normatif versus Kebatinan. Yogyakarta: LKiS.

Bustamam-Ahmad, Kamaruzzaman. 2013. Syariat Islam sebagai Living Tradition, Finiqas, Vol 2, No. 1: 152.

Nur Syam. http://nursyam.uinsby.ac.id. 